\title{
PROSPEK PENEGAKAN HUKUM UNDANG-UNDANG PENGHAPUSAN KEKERASAN DALAM RUMAH TANGGA
} (UU PKDRT)

\author{
Sabungan Sibarani \\ Dosen Tetap Fakultas Hukum Universitas Borobudur - Jakarta \\ JI. Raya Kalimalang No. 1, Jakarta Timur 13620 \\ Email :ssibarani01@gmail.com
}

Tulisan Diterima: 15-03-2016 Direvisi: 12-04-2016 Disetujui: 18-07-2016

\begin{abstract}
Abstrak
Kekerasan Dalam Rumah Tangga (KDRT) dalam ketentuan perundang-undangan di Indonesia tergolong sebuah kejahatan dengan ancaman hukum pidana karena mengakibatkan kesakitan dan penderitaan fisik maupun mental terhadap korbannya. Tujuan penelitian ini adalah untuk mengetahui prospek penegakan hukum Undang-Undang Penghapusan Kekerasan Dalam Rumah Tangga. Metode penelitian hukum yang digunakan pada penelitian ini penelitian hukum normatif yaitu suatu proses untuk menemukan aturan hukum, prinsip-prinsip hukum, maupun doktrin-doktrin hukum guna menjawab isu hukum yang dihadapi. Hasil penelitian menunjukkan bahwa menghapus tindak kekerasan dalam rumah tangga dapat dimulai dengan menghilangkan sebab-sebab dan unsurunsur pemicunya. Dalam kaitan ini, sekurang-kurang terdapat banyak cara dan usaha yang patut dilakukan agar kekerasan dalam rumah tangga terelakkan atau setidak-tidaknya dapat dikurangi intensitasnya. Prospek penegakan hukum UU PKDRT akan sulit ditegakkan karena banyak kendala dalam pelaksanaannya. Hendaknya Pemerintah mensosialisasikan UUPKDRT kepada publik atau masyarakat secara jelas dan transparan guna menghindari bias atau ketidakjelasan akan isi dan kandungan dari UUPKDRT.
\end{abstract}

Kata Kunci: Penegakan Hukum, KDRT.

\begin{abstract}
Violence in the home (domestic violence) in the provisions of law in Indonesia is a crime with the threat of criminal law, because it caused pain and suffering to the victim physically and mentally. The purpose of this study was to determine the prospects for law enforcement Law on the Elimination of Domestic Violence. Legal research methods were used in this study is a normative legal research process to find the rule of law, principles of law, and the legal doctrines in order to address the legal issues at hand. The results showed that removing the acts of domestic violence can begin by eliminating the causes and elements of the trigger. In this regard, at less there are many ways and efforts that should be done so that domestic violence inevitable or at least be reduced in intensity. Prospects the act, Law enforcement will be difficult to enforce because a lot of problems in implementation. The government should disseminate the act to the public or public is clear and transparent manner in order to avoid bias or lack of clarity of the contents and the contents of the act.
\end{abstract}

Keywords: Law Enforcement, domestic violence. 


\section{PENDAHULUAN}

\section{Latar Belakang}

Keprihatianan masyarakat terutama kaum perempuan dan relawan Lembaga Swadaya Masyarakat terhadap banyaknya kasus-kasus kekerasan dalam rumah tangga merupakan salah satu faktor pendorong dibentuknya Undang-Undang Nomor 23 Tahun 2004 tentang Penghapusan Kekerasan Dalam Rumah Tangga (UU PKDRT). Kelahiran undang-undang ini memang tidak dapat dilepaskan dari semangat jaman yang bersifat global tentang tuntutan perlunyapenghapusankekerasan terhadapkaum perempuan dan anak, yang dipandang sebagai kelompok yang paling rentan terhadap perlakuan keras.Disahkannya UU PKDRT tersebut, merupakan suatu pemikiran yang komprehensif dari negara dengan political will untuk memperhatikan dan memberikan perlindungan bagi korban kekerasan dalam rumah tangga. Namun yang menjadi kendala adalah upaya untuk mengungkap bentuk kekerasan ini tidaklah mudah, selain karena pemahaman/kesadaran masyarakat tentang kekerasan dalam rumah tangga belum sepenuhnya dipahami sebagai bentuk pelanggaran HAM, juga kekerasan dalam bentuk ini masih dilihat dalam ranah privat.

Kekerasan yang dimaksudkan oleh Undangundang ini diartikan sebagai setiap perbuatan terhadap seseorang terutama perempuan, yang berakibat timbulnya kesengsaraan atau penderitaan secara fisik, seksual, psikologis, dan/atau penelantaran rumah tangga termasuk ancaman untuk melakukan perbuatan, pemaksaan atau perampasan kemerdekaan secara melawan hukum dalam lingkup rumah tangga.

Pembentukan UU PKDRT, yang memuat kriminalisasi terhadap perbuatan kekerasan pada perempuan dan anak, merupakan upaya yang telah dirintis sejak lama untuk mewujudkan lingkungan sosial yang nyaman dan tentram bebas dari kekerasan. Idealisme ini tentulah bukan sesuatu yang berlebihan, di tengah kehidupan abad ke-21 yang telah serba sangat maju, terasakan sebagai suatu kejanggalan, manakala lingkungan hidup yang seyogyanya dapat memberikan suasana yang memberikan perasaan termanusiakan sepenuhnya ternyata sebaliknya menjadi lingkungan yang dipenuhi kekerasan atau perilaku barbar. Dengan demikian keberhasilan penegakan hukum UU PKDRT ini menjadi dambaan banyak pihak yang merindukan suasana kehidupan damai di dalam rumah tangga. ${ }^{1}$

Secara sosiologis, kekerasan merupakan sikap atau tindakan yang dipandang sangat tercela.Oleh karena penegakan norma-norma etika atau moral secara umum bersumber pada kesadaran dalam diri setiap orang, maka dalam situasi seperti sekarang ini tampaknya sangat sulit diharapkan penghapusan kekerasan (dalam rumah tangga) dilakukan diluar kerangka pendekatan yang sifatnya sistematis. Oleh karenanya kemudian dilakukan pendekatan yang sistematis dengan diaplikasikan/melalui sarana hukum pidana yakni dengan mengkriminalisasikan perbuatan kekerasan terhadap perempuan dan anak.

\section{Rumusan Masalah}

Berdasarkan latar belakang pemikiran sebagaimana diuraikan di atas, masalah yang ingin dibahas adalah Bagaimana prospek penegakan hukum Undang-undang Penghapusan Kekerasan Dalam Rumah Tangga?

\section{Tujuan Penelitian}

Tujuan penelitian ini adalah untuk mengetahui prospek penegakan hukum UndangUndang Penghapusan Kekerasan Dalam Rumah Tangga.

\section{Metodologi Penelitian}

Metode penelitian yang digunakan pada penelitian ini penelitian adalah studi pustaka dengan menekankan pada proses untuk menemukan aturan hukum, prinsip-prinsip hukum, maupun doktrin-doktrin hukum guna menjawab isu hukum yang dihadapi.

\section{PEMBAHASAN}

\section{Kekerasan Dalam Rumah Tangga (KDRT)}

Kekerasan Dalam Rumah Tangga (KDRT) bagaikan siklus yang sulit untuk dihentikan,

\footnotetext{
1 Esmi Warassih, Pranata Hukum Sebuah Telaah Sosiologis, (Semarang: Suryandaru Utama, 2000), hlm. 70 .
} 
pelaku bisa menyesal karena perbuatannya, namun tak jarang kekerasan yang berbasis gender ini selalu dari waktu ke waktu terus meningkat, salah satu penyebab terjadinya kekerasan di dalam rumah tangga ini bisa terjadi karena faktor budaya patriaki serta juga di lihat dari nilai masyarakatnya yang selalu ingin hidup harmonis sehingga cendrung yang selalu di salahkan adalah perempuan. Perlu di ketahui bahwa batasan pengertian Penghapusan Kekerasan Dalam Rumah Tangga (PKDRT) yang terdapat di dalam undang-undang No. 23 tahun 2004 Tentang Penghapusan Kekerasan Dalam Rumah tangga adalah "Setiap perbuatan terhadap seseorang terutama Perempuan yang berakibat timbulnya kesengsaraan, atau penderitaan secara fisik, seksual, psikilogis, atau penelantaran rumah tangga, Yang menpunyai ancaman untuk melakukan perbuatan, pemaksaan, atau perampasan kemerdekaan secara melawan Hukum dalam lingkungan rumah tangga" (Pasal 1 ayat (1).

Mengingat Undang-Undang tentang KDRT merupakan hukum Publik, privat maupun administratif yang di dalamnya ada ancaman Pidana Penjara atau Denda bagi yang melanggarnya, kebanyakan dari korban Kekerasan dalam Rumah Tangga ini biasanya memilih penyelesaiannya secara Privat (Perdata) dengan cara perceraian, yang siap menghadapi suatu dilema sebagai predikat janda dan selalu mendapat sorotan Negatif dari penilaian masyarakat. maka masyarakat luas khususnya kaum lelaki dalam kedudukan sebagai kepala keluarga sebaiknya mengetahui apa itu kekerasan dalam rumah tangga (KGRT). ${ }^{2}$ Adapun tentang siapa saja yang termasuk dalam lingkup rumah tangga dalam UU no 23 Tahun 2004 ini adalah :

Suami, Isteri, dan Anak, termasuk anak angkat dan anak Tiri. Orang-orang yang mempunyai hubungan keluarga dengan Suami, istri yang tinggal menetap dalam rumah tangga seperti mertua, menantu, ipar dan besan. Orangorang yang bekerja atau membantu dalam rumah tangga dan menetap tinggal dalam Rumah tangga seperti Pembantu Rumah tangga Pasal 2 UU No 3 Tahun 2004 ini pun mungkin terjadi

2 Fakih, Mansour, Diskriminasi dan Beban Kerja Perempuan: Perspektif Gender, (Yogyakarta: CIDESINDO, 2008), hlm. 18. kekerasan yang dilakukan oleh suami terhadap anggota keluarga yang jelas-jelas pelanggaran terhadap Hak asasi manusia dan martabat kemanusian serta bentuk diskriminasi.

Dalam Pasal 5 UU No 23 Tahun 2004 menyatakan bahwa setiap orang dilarang melakukan kekerasan dalam Rumah Tangga terhadap orang dalami ingkup suatu Rumah Tangga melakukan kekerasan seperti: ${ }^{3}$

1. Kekerasan Fisik, yang mengakibatkan rasa sakit, jatuh sakit atau luka berat.

2. Kekerasan Psikis yang mengakibatkan rasa ketakutan, hilangnya rasa percaya diri, hilangnya kemammpuan untuk bertindak,rasa tidak berdaya dan lain-lain.

3. Kekerasan Seksualyang berupa pemaksaan seksual dengan cara yang tidak wajar baik untuk suami maupun untuk orang lain untuk tujuan komersil atau tujuan tertentu.

4. Penelantaran rumah tangga yang terjadi dalam lingkup rumah tangganya, yang mana menurut Hukum di wajibkan atasnya untuk memberikan kehidupan yang layak atas rumah tangga nya sendiri.

Dari definisi tersebut terlihat UU ini sematamata tidak hanya melindungi kepentingan perempuan dewasa saja tetapi juga untuk mereka yang tersubordinasi, seperti juga lakilaki yang dewasa maupun masih anak-anak juga dapat perlundungan dari UU kekerasan dalam rumah tangga ini. Selain itu penelantaran juga berlaku bagi setiap orang yang mengakibatkan ketergantungan ekonomidengancara membatasi atau melarang untuk bekerja yang layak di dalam atau di luar rumah tangga, sehingga korban berada dibawah kendali orang tersebut. Bagi korban KDRT undang-undang telah mengatur akan hak-hak yang dapat di tuntut ke pada pelakunya antara lain:

a. Perlindungan dari pihak keluarga, Kepolisian, Kejaksaan, Pengadilan, Advokad, lembaga sosial atau pihak lainnya maupun atas penetapan perintah perlindungan dari Pengadilan.

3 Mohtar Mas'oed, et.al (eds.), Kekerasan Kolektif: Kondisi dan Pemicu, (Yogyakarta: P3PK UGM, 2000), hlm. 94. 
b. Pelayanan kesehatan sesuai dengan kebutuhan medis.

c. Penanganan secara khusus berkaitan dengan kerahasian Korban.

d. Pendampingan oleh pekerja sosial atau lembaga bantuan hukum.

e. Pelayanan bimbingan Rohani.

Bila ditinjau dari perspektif hukum, pemerintah telah berupaya melindungi kaum perempuan dengan diratifikasi nya konvensi mengenai penghapusan segala bentuk diskriminasi terhadap Perempuan (Convention on the Elimination All Form of Discrimination Against Woment) melalui UU Nomor 7 tahun 1984 artinya secara yuridis Indonesia telah mengikatkan diri untuk melaksanakan ketentuanketentuan dalam konvensi wanita tersebut.

Selain itu korban KDRT juga berhak untuk mendapatkan pelayanan demi pemulihan korban dari tenaga kesehatan, pekerja sosial, relawan sosial dan lainnya.Dalam UU PKDRT, Pemerintah mempunyai kewajiban untuk merumuskan kebijakan penghapusan KDRT menyelenggarakan komunikasi, informasi dan edukasi tentang KDRT, menyelenggarakan sosialisasi dan advokasi tentang KDRT, menyelenggarakan Pendidikan dan Pelatihan sensitif dan isu KDRT serta menetapkan standar dan akreditasi pelayanan yang sensitif, memberikan hak rasa aman, tentram, dan perlindungan dalam rumah tangga sebagai mana dambaan dalam setiap orang. ${ }^{4}$

Namun apabila korban menemukan kesulitan dalam penerapan Undang-undang NO 23 tahun 2004 tentang Penghapusan Kekerasan Dalam Rumah Tangga tersebut dapat meberikan kuasa kepada keluarga atau Advokat/Pengacara untuk melaporkan KDRT ke Kepolisian (Pasal 26 ayat 2). jika yang menjadi korban adalah seorang anak-anak laporan dapat di lakukan oleh orang Tua, Wali, Pengasuh, atau anak yang bersangkutan (Pasal 27) adapun sanksi Pidana dalam Pelanggaran Undang-Undang No 23 tahun 2004 tentang PKDRT diatur dalam BAB VIII mulai dari Pasal 44 s/d Pasal 53.

4 Mohammad Kemal Dermawan, Teori Kriminologi, edisi kedua, (Jakarta: Departemen Pendidikan Nasional. Penerbit Universitas Terbuka, 2007), hlm. 40. khususnya untuk kekerasan KDRT di bidang Seksual berlaku pidana minimal 5 tahun Penjara dan Maksimal 15 tahun Penjara atau 20 tahun Penjara atau Denda antara 12 juta s/d 300 juta rupiah atau antara 25 juta s/d 500 juta rupiah (Pasal 47 dan 48 UU PKDRT) dan perlu juga untuk di ketahui bahwa pada umumnya UndangUndang No 23 tahun 2004 tentang Penghapusan Kekerasan Dalam Rumah Tangga bukan hanya di tujukan kepada seorang Suami tapi juga bisa ditujukan ke pada seorang Isteri yang melakukan kekerasan terhadap Suaminya, Anak- Anaknya, keluarganya, atau Pembantunya yang menetap tinggal dalam satu rumah tangga tersebut.

Sebuah rumah tangga dengan keluarga inti (nuclearfamily) hanya terdiri atas seorang suami, seorang istri, dan anak. Lazim pula dijumpai dalam masyarakat sebuah rumah tangga terdiri dari anggota-anggota keluarga yang lain seperti mertua, ipar, dan sanak saudara atas dasar pertalian darah maupun perkawinan dengan suami-istri bersangkutan. Selain itu, rumah tangga dalam kehidupan modern di perkotaan umumnya diramaikan lagi dengan kehadiran orang lain yang berperan sebagai pembantu. Sang pembantu bisa berasal dari kerabat atau keluarga pasangan suami-istri bersangkutan dan bisa pula orang luar.

Perilaku atau tindak kekerasan dalam rumah tangga sebagai fakta sosial bukanlah perkara baru dari perspektif sosiologis masyarakat Indonesia.Persoalan ini sudah terjadi sejak lama dan masih berlanjut hingga kini. Kekerasan dalam rumah tangga sebagaimana dimaksudkan dalam Undang-Undang Nomor 23 Tahun 2004 tersebut, Bab 1 Tentang Ketentuan Umum Pasal 2 adalah setiap perbuatan terhadap seseorang terutama perempuan, yang berakibat timbulnya kesengsaraan atau penderitaan secara fisik, seksual, psikologis, dan/atau penelantaran rumah tangga termasuk ancamanuntuk melakukan perbuatan, pemaksaan, atau perampasan kemerdekaan secara melawan hukum dalam lingkup rumah tangga. ${ }^{5}$

Selain itu, KDRT merupakan fakta sosial yang bersifat universal karena dapat terjadi dalam sebuah rumah tangga tanpa pembedaan budaya,

Otje Salman dan Anton F. Susanto, Beberapa Aspek Sosiologi Hukum, (Bandung, Alumni, 2000), hlm. 101. 
agama, suku bangsa, dan umur pelaku maupun korbannya. Karena itu, ia dapat terjadi dalam rumah tangga keluarga sederhana, miskin dan terkebelakang maupun rumah tangga keluarga kaya, terdidik, terkenal, dan terpandang. Tindak kekerasan ini dapat dilakukan oleh suami atau istri terhadap pasangan masing-masing, atau terhadap anak-anak, anggota keluarga yang lain, dan terhadap pembantu mereka secara berlainan maupun bersamaan.Perilaku merusak ini berpotensi kuat menggoyahkan sendi-sendi kehidupan rumah tangga dengan sederetan akibat di belakangnya, termasuk yang terburuk seperti tercerai-berainya suatu rumah tangga.

Tindak KDRT di Indonesia dalam rentang waktu yang panjang cenderung bersifat laten hingga jarang terungkap ke permukaan. Akibatnya, ialebihmerupakankejadiansederhana yang kurang menarik ketimbang sebagai fakta sosial yang seharusnya mendapatkan perhatian khusus dan penanangan yang sungguh-sungguh dari masyarakat dan pemerintah. Kekerasan dalam rumah tangga Indonesia di mana pun juga masih terus berlangsung dengan jumlah kasus dan intensitasnya yang kian hari cenderung kian meningkat. Media massa cetak dan elektronik Indonesia malah tak pernah lengang dari beritaberita dan informasi-informasi terbaru tentang tindak KDRT, termasuk dalam rumah tangga para selebriti.

Dalam pada itu, Lembaga Bantuan Hukum Asosiasi Perempuan untuk Keadilan (LBH APIK), merilis laporan pada 12 Mei 20014 bahwa terjadi 83 kasus kekerasan dalam rumah tangga selama empat bulan pertama 2015 di wilayah Jakarta dan sekitarnya. Sebagian besar kasus itu merupakan kekerasan suami terhadap istri. Para perempuan korban tindak kekerasan itu antara lain mengalami kekerasan fisik, psikis, dan ekonomi karena tidak dinafkahi atau diperas, dan kekerasan seksual atau kombinasi di antara semuanya itu. Perkara tersebut kemudian berakhir dengan perceraian (30 kasus), pidana (9 kasus), mediasi (6 kasus), dan konsultasi pernikahan (38 kasus). Tindak kekerasan terselubung ini baru dianggap serius dan masuk ke dalam tindak kejahatan dengan sanksi hukum pidana sejak tahun 2004 sesuai Undang-Undang Nomor 23 Tahun 2004 setelah ia makin marak dengan akibat berlapis hingga menelan korban jiwa. ${ }^{6}$

Kekerasan seksual seperti perkosaan merupakan salah satu bentuk tindak kekerasan dalam rumah tangga yang korbannya bisa lakilaki di samping perempuan.Para kriminolog sering mengatakan bahwa angka statistik kejahatan perkosaan, termasuk dalam rumah tangga, bagaikan sebuah gunung es. Data statistik tindak kekerasan ini jauh lebih kecil berbanding jumlah sesungguhnya peristiwa perkosaan yang terjadi.Dalam masyarakat yang terbuka saja tidak seluruh kasus perkosaan terungkap, apalagi dalam unit yang lebih kecil seperti keluarga.

Kekerasan dalam rumah tangga secara konseptual berbanding sejajar dengan kekerasan-kekerasan lain termasuk kekerasan politik. Sebagai pembanding terhadap persoalan ini, Gurr mendefinisikan kekerasan politik sebagai berikut: ${ }^{7}$

"all collective attacks within a political community against the political regime, its actors - including competing political groups as well as incumbents-or its policies. The concept represents a set of events, a common property of which is the actual or trheatened use of violence .... The concept subsumes revolution, ... guerilla war, coups d'atat, and riots."

Definisi di atas menunjukkan bahwa tindak kekerasan politik amat luas cakupannya, yang meliputi semua kejadian yang unsur utamanya adalah penggunaan atau ancaman penggunaan kekerasan yang dilakukan oleh pelaku/aktor atau kelompok aktor yang menentang penguasa negara.Selain itu, Galtung mendefinisikan kekerasan dalam pengertian yang lebih luas sebagai "any avoidable impediment to selfrealization", yang berarti segala sesuatu yang menyebabkan orang terhalang untuk

6 Estu Rakhni Fanani, "Undang-Undang Nomor 23 Tahun 2004 TentangKekerasan Dalam Rumah Tangga, Antara Terobosan Hukum Dan Fakta Pelaksanaannya", Jurnal Legislasi Indonesia, Vol. 5 No. 3 September 2008, hlm. 12.

7 Ted Rober Gurr, Why Men Rebel.(Princeton, NJ: Princeton University Press, 1970), pages. 203. 
mengaktualisasikan potensi dirinya secara wajar. $^{8}$

Koseptualisasi tentang kekerasan yang diajukan Galtung tersebut mencakup dua jenis kekerasan, yaitu kekerasan langsung atau personal dan kekerasan tidak langsung atau struktural.Kekerasan langsung adalah kekerasan yang dilakukan oleh satu atau sekelompok aktor kepada pihak lain (violence-as-action), sementara kekerasan struktural terjadi begitu saja (built-in) dalam suatu struktur (violence-asstructure) atau masyarakat tanpa aktor tertentu atau dilakukan oleh seseorang atau sekelompok orang dengan menggunakan alat kekerasan.

Berdasarkan dua definisi pembanding tersebut, KDRT dapat diartikan sebagai tindakan penggunaan kekuasaan atau wewenang secara sewenang-wenang tanpa batasan (abuse of power) yang dimiliki pelaku, yaitu suami atau istri maupun anggota lain dalam rumah tangga, yang dapat mengancam keselamatan dan hakhak individual masing-masing dan atau anggota lain dalam rumah tangga seperti anak-anak, mertua, ipar, dan pembantu.

Penggunaan kekuasaan secara sewenangwenang dimungkinkan karena situasi yang terbentuk dalam rumah tangga di mana dominasi yang satu ke atas yang lain begitu kuat disebabkan beberapa faktor seperti akan dijelaskan kemudian. Dominasi tersebut akan terus berlanjut selama tingkat ketergantungan pihak yang didominasi kepada yang dominan tetap tinggi.

Banyak hal positif dapat dipelajari dan diambil manfaatnya dari hubungan-hubungan sosial yang dibangun dalam rumah tangga. KDRT sesungguhnya dapat dihindarkan jika suatu rumah tangga ditegakkan dengan menjalankan berbagai prinsip positif dan etika luhur berdasarkan fungsi anggota menurut hak dan kewajiban masing-masing.

Menghapus tindak KDRT dapat dimulai dengan menghilangkan sebab-sebab dan unsurunsur pemicunya. Dalam kaitan ini, sekurangkurang terdapat banyak cara dan usaha yang patut dilakukan agar KDRT terelakkan atau setidak-tidaknya dapat dikurangi intensitasnya.
Implementasi UU KDRT dalam upaya penegakan hukum secara berafiliasi terhadap upaya-upaya konkrit dalam mencegah KDRT, diantaranya adalah: ${ }^{9}$

\section{Memperkuat Jaringan Sosial}

Rumah tangga yang dibentuk dari simpulsimpul, yaitu angggota-anggota di dalamnya sesungguhnya merupakan struktur sosial yang mencerminkan jaringan sosial yang diikat dengan tipe relasi spesifik seperti nilai, visi, dan ide bersama serta keturunan. Idealnya, tipe-tipe relasi spesifik itu lah yang berfungsi mengikat aktor-aktor dalam rumah tangga yang terdiri dari anggotaanggotanya seperti suami, istri, anak dan sebagainya dalam suatu hubungan antarsesama yang kuat.Keberhasilan suatu rumah tangga dalam mencapai tujuan-tujuan idealnya, termasuk menghindari terjadinya KDRT, sangat bergantung kepada kekuatan hubungan antarindividu bersangkutan.

Semua anggota dalam suatu rumah tangga, terutama suami atau istri yang menjadi antra aktor utama dalam rumah tangga dengan latarbelakang sosial yang berbeda seharusnya dapat memperkuat struktur jaringan sosial rumah tangga mereka. Caranya ialah dengan selalu berusaha untuk menyamakan visi, menyeragamkan nilai-nilai dan menyatukan ide dan gagasan masing-masing ke dalam idelaisme dan cita-cita bersama, meskipun untuk itu toleransi yang memadai dari masing-masing pihak amat diperlukan.

Dengan demikian, kekuasaan dan dominasi yang satu terhadap yang lain yang menjadi antara penyebab KDRT akan hilang dengan sendirinya bersamaan dengan hilangnya KDRT.

\section{Memahami Kearifan Budaya Lokal}

Tidak seorang pun anggota dalam rumah tangga hidup begitu saja tanpa nilai-nilai dasar yang membentuk kepribadiannya serta yang mengarahkannya berpikir

9 Henny Wiludjeng, Attashendartini Habsjah dan Dhevy Setya Wibawa, Dampak Pembakuan Peran Gender terhadap Perempuan Kelas Bawah di Jakarta (Jakarta: LBH-APIK, 2005), hlm. 88. 
dan berperilaku.Nilai-nilai dasar tersebut dapat bersumber dari ajaran agama maupun tradisi atau kebudayaan lokal di lingkungan sekitarnya. Setiap tradisi dan budaya tentu memiliki nilai-nilai positif yang mencerminkan kearifan lokal (local wisdom) sendiri yang berbeda antara satu budaya dengan budaya yang lain, termasuk konsep tentang rumah tangga ideal.

Meskipun agama sepatutnya menjadi acuan dan sumber nilai yang utama mengatasi sumber nilai yang lain, seringkali tradisi dan budaya lokal dalam praktik kehidupan sehari-hari suatu rumah tangga menjadi begitu penting. Karena begitu pentingnya, maka kesalahan dalam memahami dan menempatkan nilai-nilai tradisi dan budaya itu seringkali menjadi penyebab munculnya konflik antarindividu yang berakibat terjadinya tindak KDRT. Oleh karena itu, suami, istri, dan anggota lain dalam rumah tangga dengan latarbelakang tradisi dan budaya yang berbeda perlu memahami dan mengekpresikan nilia-nilai positif budaya masing-masing dalam kesalehan lingual atau kesalehan verbal melalui ucapan dan tuturkata yang santun, sejuk, damai dan menyenangkan. Selain itu, mereka juga dapat menunjukkannya dalam kesalehan sosial melalui perilaku yang sopan, sikap pemaaf, dan sebagainya.

Pemahaman yang memadai tehadap nilainilai budaya lokal akan membantu setiap individu tidak sampai terjebak ke dalam pengaruh budaya luar dalam bungkusan globalisasi yang kini gencar melanda seluruh pelosok dunia. Meskipun banyak juga aspek positif yang dapat diserap daripadanya, akan tetapi globalisasi berpotensi kuat menggiring manusia ke arah situasi anomie. Ini cenderung terjadi karena globalisasi antara lain dicirikan oleh derasnya laju transformasi berbagai bentuk budaya, sikap, dan pandangan hidup manusia modern yang tidak semuanya tepat dari sisi pandang budaya lokal (Indonesia) dan agama.

\section{Memperkuat Fondasi dan Bangunan Ekonomi Keluarga}

Menjalani hidup berkeluarga seadanya dalam tingkat kepasarahan yang tinggi tampaknya kini tidak lagi sesuai dalam kehidupan yang semakin kompleks dengan sederatan tuntutan yang mesti dipenuhi. Kompleksitas kehidupan tidak hanya berlaku di perkotaan tetapi juga di pedesaan dengan sejumlah persamaaan dan perbedaannya. Beban hidup yang terlalu berat dapat mengakibatkan ketidakseimbangan emosi hingga memicu terjadinya tindakan KDRT. Kerana itu, seluruh anggota dalam suatu rumah tangga sesuai kesanggupan masingmasing harus melakukan usaha-usaha yang dapat memperkuat fondasi dan struktur bangunan ekonomi keluarga mereka.

Tanggungjawab utama memang berada di atas pundak suami. Sebagai kepala keluarga, suami mesti bekerja keras dalam bidang yang ia tekuni dan tidak mudah goyah oleh pengaruh-pengaruh luar yang menyebabkan ia mudah melepaskan pekerjaan utamanya. Selain kukuh dengan pekerjaan utama, suami juga ditunut untuk selalu berusaha mencari peluang untuk dapat melakukan inovasi dan menciptakan kreasi-kreasi baru meskipun tidak sejalan dengan bidang pekerjaannya yang utama.

Selain itu, istri sebagai anggota utama keluarga yang kedua juga dapat melakukan hal yang sama seperti suaminya, lebih-lebih bila dia juga ikut bekerja dalam sektor formal atau informal. Kecuali anak yang sudah bekerja, anak yang sedang menempuh pendidikan tentu tidak dituntut untuk dapat menghasilkan pendapatan tambahan bagi keluarga. Akan tetapi ia tetap dapat melakukan penguatan ekonomi keluarga secara pasif dengan berhemat dan meminta kedua orangtuanya untuk mememenuhi kebutuhannya yang pokok-pokok saja.

\section{Mengamalkan Ajaran Agama}

Agama, khususnya Agama Islam, adalah ajaran yang merupakan sumber dari segala sumber nilai. Sebagai sebuah ajaran, dan bukan sistem nilai, nilai-nilai 
yang terkandung dalam ajaran Islam akan merasuk dalam hati.

\section{PENUTUP}

\section{Kesimpulan}

Dilihat dari segi sosiologi hukum, prospek penegakan hukum UU PKDRT akan sulit ditegakkan karena banyak kendala dalam pelaksanaannya, terutama kultur budaya masyarakat Indonesia yang patriakhi yakni mendudukan laki-laki sebagai makhluk superior/ kuat dan perempuan sebagai makhluk inferior/ lemah.

KDRT dalam perspektif sosiologis merupakan fakta sosial yang bersifat lintas etnik, kepercayaan, dan kawasan yang dapat dijumpai di masyarakat dari berbagai golongan, status dan lapisan sosial hampir di semua tempat. Sebagai sebuah tindakan antisosial dan anti kemanusiaan, KDRT dapat terjadi secara tibatiba dan terencana oleh dan terhadap semua aktor atau anggota dalam suatu rumah tangga yang bertindak sebagai pelaku maupun korban.

Tindak KDRT dalam berbagai bentuk dan kasus terjadi karena dominasi dan penggunaan kekuasaan yang berlebihan oleh pelaku. Namun demikian, sejumlah faktor internal pada pribadi aktor-aktor pelaku dalam rumah tangga, dan faktor-faktor eksternal yang berpusat pada sistem nilai budaya lokal dan perubahan sosial yang berlangsung cepat, turut berperan sebagai penyebab dan pemicunya.

\section{Saran}

Undang-undang yang berkenaan Kekerasan Dalam Rumah Tangga (KDRT) memerlukan waktu baik bagi Pemerintah untuk mensosialisasikan undang-undang tersebut maupun bagi masyarakat.apa lagi Suami dalam Pimpinan Rumah Tangga merasa berkuasa terhadap keluarganya dan dari kaum wanita merasa ada pembatasan norma agama yang harus di jalanin untuk berhadapan dengan suami sebagai kepala rumah tangganya sendiri. Pada hal dalam rumah tangga tersebut ada Hak dan Kewajiban masing-masing yang di atur oleh Agama.Dari berbagai hasil penelitian maupun laporan kasus dari lembaga-lembaga yang perduli terhadap perempuan menunjukan korban kekerasan dalam rumah tangga yang terus meningkat ini.Secara yuridis kesadaran dari semua pihat baik secara nasional maupun internasional suudah harus di realisasikan melalui sarana hukum.

Perluasan tindak KDRT di masyarakat tidak patut dibiarkan berkembang terus tanpa kendali. Berbagai usaha dan cara mesti dilakukan oleh semua pihak sebagai wujud pekedulian terhadap persoalan sosial bersama, terutama oleh mereka yang terkait lansung dengannya sebagai pelaku dan korban. Semua langkah menuju ke arah penghapusan tindak KDRT itu dapat dimulai dari usaha-usaha untuk memutus mata rantai penyebab dan pemicunya melalui penguatan jaringan sosial, pemahaman kembali nilai-nilai positif yang terdapat dalam kearifan budaya lokal (local wisdom), dan penguatan fondasi dan struktur bangunan ekonomi keluarga melalui inovasi dan kreasi baru. Mengatasi semuanya itu adalah menjadikan ajaran agama sebagai sumber nilai yang utama melalui langkahlangkah pendalaman dan pelaksanaan ajaranajarannya, khususnya ajaran tentang tata cara ideal hidup berkeluarga.

\section{DAFTAR PUSTAKA}

Dermawan, Mohammad Kemal. TeoriKriminologi. Edisi Kedua.(Jakarta: Departemen Pendidikan Nasional. Penerbit Universitas Terbuka, 2007).

Fanani, Estu Rakhni. "Undang-Undang Nomor 23 Tahun 2004 Tentang Kekerasan Dalam Rumah Tangga, Antara Terobosan Hukum Dan Fakta Pelaksanaannya", Jurnal Legislasi Indonesia, Vol. 5 No. 3 September 2008.

Gurr, Ted Rober. Why Men Rebel. (Princeton, NJ: Princeton University Press, 1970).

Mansour, Fakih. Diskriminasi dan Beban Kerja Perempuan:PerspektifGender.(Yogyakarta: CIDESINDO, 2008).

Mas'oed, Mohtar. et.al (eds.).Kekerasan Kolektif: Kondisi dan Pemicu.(Yogyakarta: P3PK UGM, 2000).

Salman, Otje dan Anton F. Susanto.Beberapa Asoek Sosiologi Hukum.(Bandung, Alumni, 2000). 
Warassih, Esmi. Pranata Hukum Sebuah Telaah

Sosiologis.(Semarang: Suryandaru Utama, 2000).

Wiludjeng, Henny, Attashendartini Habsjah dan Dhevy Setya Wibawa, Dampak Pembakuan Peran Gender terhadap Perempuan Kelas Bawah di Jakarta.(Jakarta: LBH-APIK, 2005). 


